\title{
Formas de integración social en un espacio en construcción. El caso del Territorio Nacional del Chaco a partir de los años veinte*
}

\begin{abstract}
Resumen
Este trabajo aborda el tema del poblamiento en el espacio interior del Territorio Nacional del Chaco en Argentina, hecho que surgió como consecuencia del proceso colonizador y del apogeo algodonero ocurridos simultáneamente a partir de la década del veinte en el siglo pasado. En este sentido, se describen las características generales de los grupos inmigratorios externos e internos que arribaron a esta jurisdicción y se analizan las formas mediante las cuales dichas poblaciones se vincularon durante el proceso de integración social. Las condiciones de vida, los ámbitos de interrelación y las prácticas de sociabilidad ocupan un lugar central en la presente investigación.
\end{abstract}

Palabras clave: Chaco, territorio, integración, social.

Referencia para citar este artículo: MARI, Oscar Ernesto (2016). "Formas de integración social en un espacio en construcción. El caso del Territorio Nacional del Chaco a partir de los años veinte", en Anuario de Historia Regional y de las Frontera. 21 (1). pp. 105-131.

Oscar Ernesto Mari: Doctor en Historia por la Universidad del Salvador, Argentina. Investigador categoría Independiente del CONICET, Argentina. Profesor regular del Departamento de Historia de la Facultad de Humanidades de la Universidad Nacional del Nordeste (UNNE), Resistencia, Chaco, Argentina. Correo electrónico: oscar.mari@yahoo.com.ar.

\footnotetext{
* Artículo de investigación científica, resultado de la investigación financiada por el CONICET-Argentina, a través el proyecto PIP-CONICET n. ${ }^{\circ} 11220110100724$, co-dirigido por el autor.
} 


\title{
Types of Social Integration in a Space under Construction. The Case of the Chaco National Territory from the 1920's
}

\begin{abstract}
This article is about the settlement process in the interior space of the Chaco National Territory in Argentina, a phenomenon that resulted from the colonizing process and the cotton growing peak because these two events occurred simultaneously from the 1920 's. This paper describes the general characteristics of both external and internal immigrating groups that arrived to this jurisdiction. Furthermore, the author analyzes the relation of these population settlements to the social integration process. Living conditions, interrelation spaces, and sociability practices are the core of this research.
\end{abstract}

Keywords: Chaco, territory, integration, social.

\section{Formas de integração social em um espaço em construção. $O$ caso do Território Nacional do Chaco a partir dos anos vinte}

\begin{abstract}
Resumo
Este trabalho aborda o tema do povoamento no espaço interior do Território Nacional do Chaco na Argentina, feito que despontou como consequência do processo colonizador e do apogeu algodoeiro ocorridos simultaneamente a partir da década de vinte do século passado. Neste sentido, se descrevem as características gerais dos grupos migratórios externos e internos que chegaram a esta jurisdição e se analisam as formas mediante as quais estas populações se vincularam durante o processo de integração social. As condições de vida, os âmbitos de inter-relação e as práticas de sociabilidade ocupam um lugar central na presente investigação.
\end{abstract}

Palavras-chave: Chaco, território, integração, social. 


\section{Introducción}

Cuando se emprenden estudios sobre el Chaco de los años veinte al cuarenta, una de las características que aflora con nitidez es la notable corriente inmigratoria que afluyó para insertarse en el proceso colonizador del espacio interior de este Territorio Nacional argentino.

Desde la época colonial, el llamado Chaco Austral había sido parte de la región genéricamente denominada Gran Chaco, y permaneció bajo dominio indígena hasta fines del siglo XIX. La ocupación efectiva de esta sección por parte del Estado Argentino se inició de manera decidida al finalizar la guerra de la Triple Alianza (1870), y atravesó distintas instancias de organización, pasando de ser una Gobernación (1872-1884) a un Territorio Nacional (1884-1951), hasta convertirse finalmente en Provincia a partir de esta última fecha. Hasta su provincialización, el Estado Nacional mantuvo al Chaco bajo un régimen tutelado, por lo cual las políticas públicas y los funcionarios designados dependieron enteramente de los poderes centrales.

Al igual que los demás Territorios Nacionales argentinos, el Chaco fue poblado con contingentes inmigratorios regionales o europeos que arribaron en distintas etapas, de acuerdo con el impulso de las políticas colonizadoras o las demandas de los ciclos económicos vigentes.

En 1878 arribaron los primeros colonos provenientes del norte de Italia, los cuales se instalaron en las inmediaciones de lo que luego sería la capital del Chaco Austral (Resistencia) y dieron comienzo así a la primera etapa de colonización con inmigrantes europeos, en el sector oriental. Casi al mismo tiempo, y en coincidencia con el surgimiento del llamado ciclo forestal o del tanino, arribaron escalonadamente jornaleros provenientes de la vecina provincia de Corrientes, y luego del Paraguay, quienes se incorporaron como trabajadores manuales en las faenas inherentes a las actividades forestales o azucareras, siempre en el sector oriental.

En la segunda etapa significativa de poblamiento que se inició a comienzos de la década del veinte juntamente con el surgimiento del llamado ciclo algodonero y la expansión hacia el interior del Territorio, la población pasó de 46.274 habitantes en 1914, a 60.500 en 1920; luego a 214.000 en 1934, y llegó finalmente a 360.000 en 1940.Esto que se conoce como la segunda oleada inmigratoria, denominación que procura una correspondencia secuencial con la ocurrida a fines del siglo XIX en el sector oriental, se distribuyó fundamentalmente en el área central y sud-oeste del Chaco, en donde simultáneamente se desarrolló la expansión agrícola basada en el cultivo algodonero. En estos nuevos espacios colonizados, particularmente en los departamentos denominados Napalpí y Campo del Cielo, se radicaron buena parte de los nuevos contingentes arribados y las colonias que los agruparon fueron, a la sazón, las que dieron el sustento y el progreso a las localidades vinculadas a la explotación del textil. 
Cuenta partir de la heterogeneidad de los grupos sociales participantes de este proceso, nos hemos preguntado de qué forma se produjo su inserción en un medio geográfica y culturalmente distinto al de sus lugares de origen (sobre todo en el caso de los extra-regionales); cómo es que sobrellevaron los drásticos cambios que supuso el desarraigo y la acelerada adaptación que debieron emprender para manejar sus respectivas actividades; de qué medios y estrategias se valieron para sortear los obstáculos que presentaban una jurisdicción que aún no se había organizado mínimamente en algunos aspectos; y finalmente, de qué manera encararon sus vínculos sociales fuera de sus respectivas colectividades, teniendo presente la diversidad de nacionalidades afincadas en este espacio.

Precisamente y en este sentido, uno de los primeros puntos que hemos estimado repasar para comenzar a responder estas preguntas es el referido a las características diferenciadoras de este heterogéneo conjunto social, a partir de las procedencias, los volúmenes ingresados, la composición, los lugares en los que se afincaron, y las actividades u oficios a los que se dedicaron con preferencia. Con esto, pretendemos realizar luego una descripción de hábitos y de costumbres que permitan señalar adaptaciones, articulaciones, o eventuales simbiosis en los distintos niveles de integración; en otras palabras, que permita dimensionar la incidencia de las influencias imperantes y también los tiempos que insumió este proceso.

En este abordaje puede que el análisis de algunos grupos o colectividades en particular prevalezca sobre otros, pero en buena medida ello tiene cierta lógica. Dado que fueron los inmigrantes europeos quienes sufrieron mayormente el esfuerzo de la adaptación debido a los contrastes de este medio con sus lugares de origen, posiblemente aparezca con mayor detalle las referencias sobre sus respectivas formas de vida en esta tierra de adopción. Además de los europeos, otros grupos sociales pueden también aparecer tratados con un mayor empeño, pero por opuestos motivos. Por ejemplo: los conjuntos que provinieron de regiones vecinas al Chaco para alquilar su mano de obra, lejos de padecer el desarraigo o un traumático proceso de adaptación, habrán de ser ellos los transmisores de pautas culturales y costumbres, quienes influirán casi inmediatamente en esta sociedad en formación, y a mediano plazo, constituirán elementos distintivos de la identidad colectiva de este espacio.

La idea es, en definitiva, perfilar el comportamiento de los grupos pobladores arribados, quienes, ya fuese por una fuerte presencia económica o social o bien por la mayoría numérica, se erigieron como los más representativos del Chaco de la primera mitad de la centuria. Simultáneamente, pretendemos también mostrar los incipientes procesos de integración (o convivencia) operados dentro de esta diversidad étnica y cultural. 
Mapa 1. División política actual del espacio de estudio.

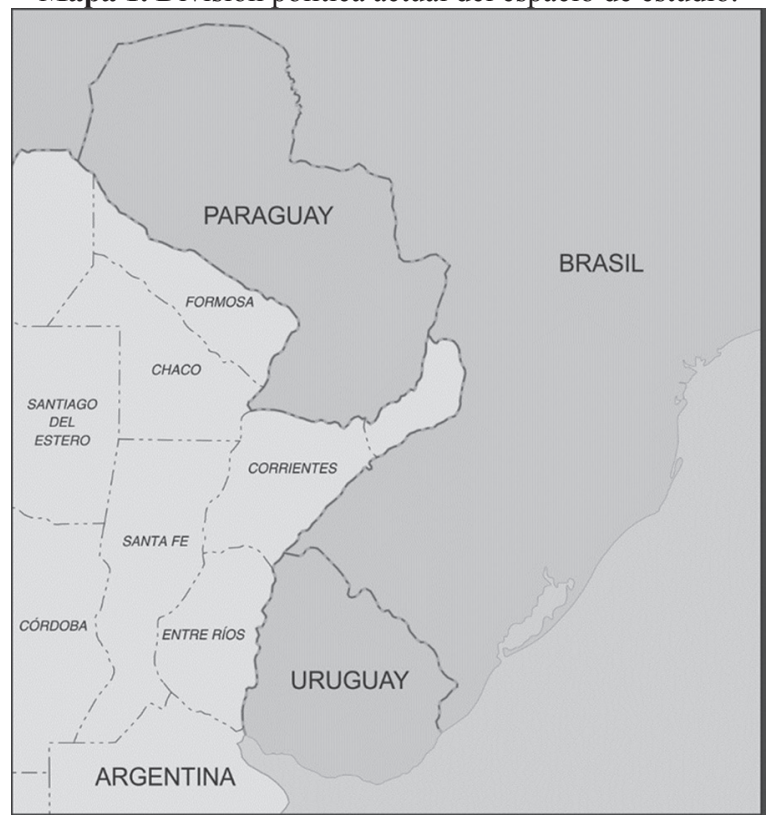

Fuente: elaboración propia.

Diseño Gráfico: Cristian Toullieux (Personal Técnico del IIGHI-CONICET/UNNE)

Mapa 2. Territorios Nacionales en Argentina (fines de siglo XIX y primera mitad del veinte).

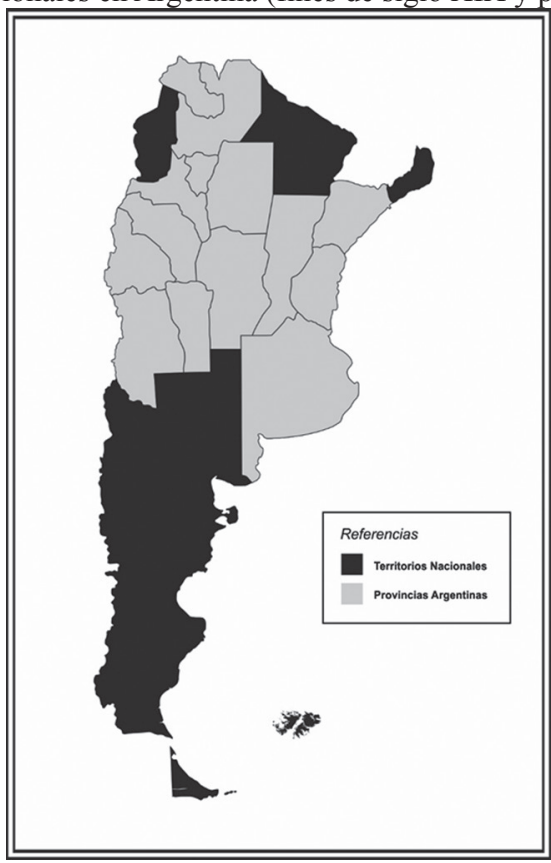

Fuente: elaboración propia.

Diseño Gráfico: Cristian Toullieux (Personal Técnico del IIGHI-CONICET/UNNE) 
Formas de integración social en un espacio en construcción. El caso del Territorio Nacional...

Mapa 3. Territorio Nacional del Chaco entre las décadas de 1930 y 1940.

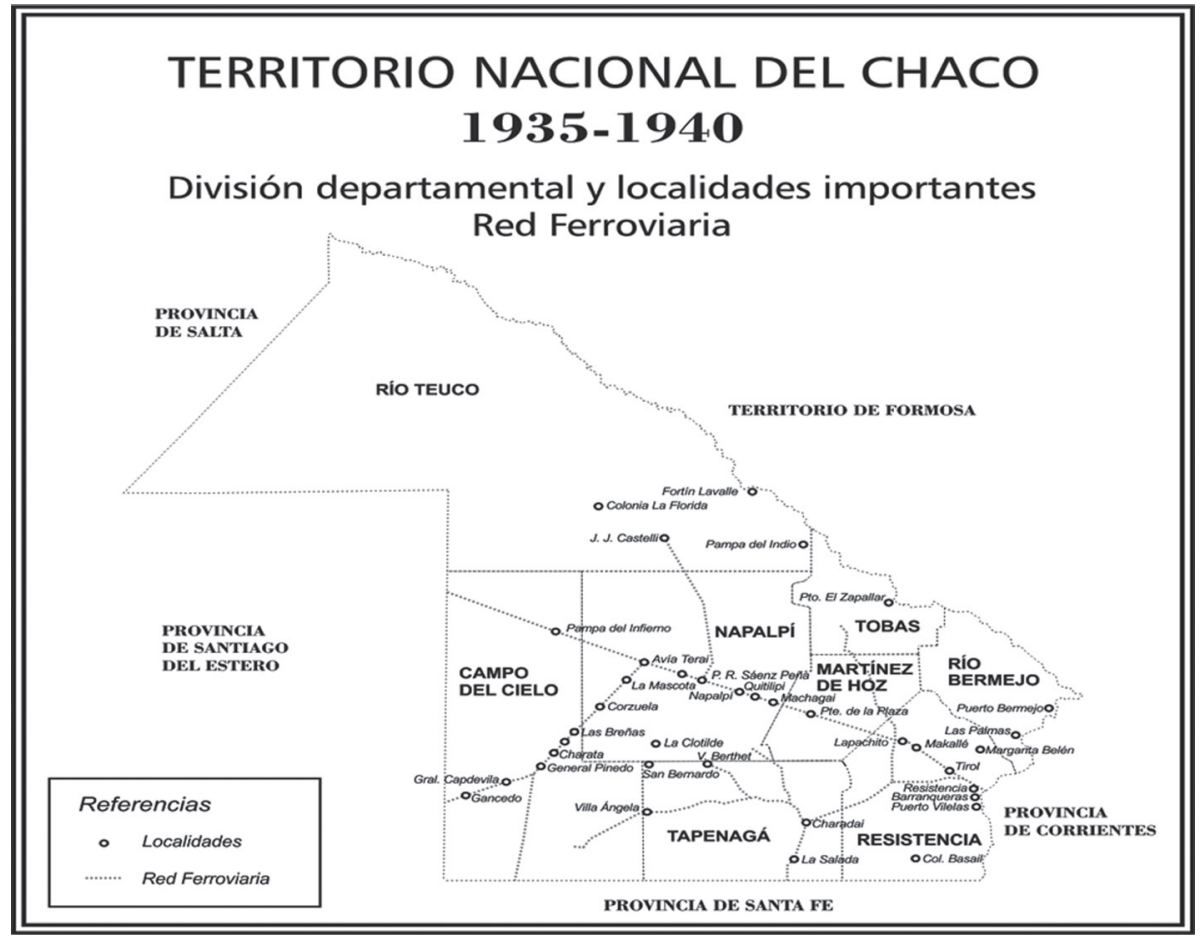

Fuente: elaboración propia.

Diseño Gráfico: Cristian Toullieux (Personal Técnico del IIGHI-CONICET/UNNE)

\section{Características generales de los grupos humanos arribados al Chaco durante la etapa del auge algodonero}

\section{a) Los grupos de origen europeo}

Durante las décadas del veinte y del treinta, tanto en los medios periodísticos como en parte de la literatura de la época, comenzó a proyectarse la imagen de un Chaco gringo a raíz del importante número de inmigrantes europeos que se instalaron en el interior del Territorio luego de la culminación de los ramales ferroviarios que lo atravesaron de Este a Oeste. Si bien esta imagen no se correspondió enteramente con la realidad, ya que los grupos provenientes de Paraguay o de provincias vecinas fueron mucho más numerosos, la súbita afluencia de los europeos y la fuerte "impresión cromática" que causaron estas personas blancas y rubias que descendieron de los trenes y que ocuparon las colonias, alimentó esa idea.

Este fenómeno se había acelerado especialmente cuando, luego de la fundación de pueblos a la vera de las vías, se atrajo inmigración europea mediante algunas 
iniciativas gubernamentales dispuestas entre 1921 y $1923^{1}$.Como consecuencia de ello, entre 1920 y 1930 se internaron 14.894 inmigrantes europeos en el Chaco, y más de 7.000 lo harían en la siguiente década. Aproximadamente el $90 \%$ de estos europeos se afincaron en los ámbitos rurales y urbanos de localidades como Sáenz Peña (34\%); Villa Ángela (18\%); Charata (17\%), y Las Breñas (8\%). Otros pueblos vinculados a la actividad algodonera absorberían el7,5\% $\%^{2}$ restante. Las nacionalidades ingresadas específicamente en estos años se repartieron en las siguientes proporciones: polacos $(24 \%)$; italianos $(22 \%)$; yugoslavos $(13 \%)$; búlgaros (11\%); españoles (9\%); alemanes $(8 \%)$; checoslovacos $(7 \%)$, y rusos, lituanos y ucranianos aproximadamente un $(2 \%)^{3}$.

Con lo descrito anteriormente, conviene preguntar entonces: ¿cuáles fueron las características distintivas de algunos de estos grupos al momento de su llegada al Chaco?

Al seguir en parte las referencias de los historiadores chaqueños, algunos de los cuales han sido testigos directos de estos acontecimientos ${ }^{4}$, podríamos hacer algunas semblanzas, no sin antes advertir que para tal fin debe tenerse en cuenta la diferente idiosincrasia de latinos, eslavos, y germanos, que fueron a la sazón, los grupos étnicos europeos de mayor presencia en el Chaco. Esa distinción ayudará a comprender mejor los distintos tiempos del proceso de adaptación al medio por parte de los respectivos grupos.

En el caso de españoles e italianos, estos ya habían ingresado al Chaco durante la primera etapa colonizadora y se instalaron en las primigenias colonias situadas en las cercanías de los grandes ríos del Este. Ambas nacionalidades constituyeron siempre los grupos mayoritarios de la inmigración argentina. Ya en la segunda etapa inmigratoria,

\footnotetext{
${ }^{1}$ Hacia 1914 se concluyeron los ramales troncales ferroviarios que atravesaron el Chaco desde el Este hacia el Sudoeste y Norte, comunicándolo totalmente con el resto del país, e incorporando a la vez, vastos espacios aptos para la explotación agrícola. Por decreto del 11 de julio de 1921 se dispuso la creación de varias colonias agrícolas y pastoriles en el Chaco, con lo cual se produjo una oferta de tierras para la producción sin precedentes. Simultáneamente a estas medidas, se produjo en EEUU la crisis algodonera causada por la invasión de la plaga del picudo, lo cual hizo elevar considerablemente los precios internacionales del textil. Casi inmediatamente, el ministro de agricultura Tomás Le Bretón realizó en 1923 una campaña para fomentar el cultivo algodonero y atraer inmigración. Todo ello provocó una fuerte afluencia de pobladores a este Territorio Nacional.

${ }^{2}$ Beck, Hugo. "Inmigrantes Europeos en el Chaco. Transición del pluralismo al crisol", en Cuadernos de Geohistoria Regional, n. ${ }^{\circ}$ 39, IIGHI, Resistencia, Chaco, 2001, p. 63.

${ }^{3} \mathrm{La} \mathrm{Voz} \mathrm{del} \mathrm{Chaco,} \mathrm{enero} \mathrm{de} \mathrm{1930.} \mathrm{Citado} \mathrm{por} \mathrm{Beck,} \mathrm{Hugo.} \mathrm{"Inmigrantes} \mathrm{Europeos} \mathrm{en} \mathrm{el} \mathrm{Chaco.} \mathrm{Transición}$ del pluralismo al crisol", en Cuadernos de Geohistoria... Op. Cit.

${ }^{4}$ En el Chaco existen obras clásicas de historiadores regionales que han aludido al proceso de poblamiento. Se tiene el caso de Guido Miranda, quien es reconocido como un referente principal en la temática por la sistematización de los ciclos socio-económicos del Territorio en su emblemática obra Tres Ciclos Chaqueños. También se toman aquí a otros autores testigos de esta época y muy conocedores de la región, como Francisco Suáiter Martínez y José Pavlotzky, este último, residente por muchos años en el centro del Chaco. Los trabajos de Hugo Beck, de Héctor Borrini, de Enrique Schaller, y de Enrique Bruniard, especialmente los dedicados a la colonización en el Chaco, también han sido de gran utilidad para estas referencias.
} 
Formas de integración social en un espacio en construcción. El caso del Territorio Nacional...

dichas colectividades volvieron a ser numéricamente superiores, y desde luego, por afinidad cultural tuvieron una rápida integración. Las publicaciones chaqueñas de la época describían, por ejemplo, al italiano promedio afincado en el Chaco como:

[...] un exponente fiel del trabajo y de la perseverancia llevados [sic] hasta el grado de la rudeza... Siembra la tierra y construye pueblos sin saber porqué, mientras le da al país el esfuerzo para enriquecerlo. Se identifica de tal manera con nuestros hábitos y costumbres, que al poco tiempo parece rivalizar con nosotros por la preeminencia del aire nacional $[\ldots]^{5}$

Los polacos, por su parte, componían un grupo de bajo nivel educativo. Si bien estas poblaciones constituyeron un buen número de colonos agrícolas en las zonas aledañas de Charata: Las Breñas y Sáenz Peña; por su parte, Beck asegura que no fue la actividad preferencial, sino que vivieron en los centros urbanos dedicados fundamentalmente al comercio ${ }^{6}$.

Los checoslovacos se instalaron en el núcleo urbano de Sáenz Peña y en sus alrededores, en donde pronto fueron catalogados como laboriosos, mesurados, meditativos, cultos, y dignos. El historiador Guido Miranda señalaba que en general se dedicaron a la agricultura, pero una cierta porción se distribuyó en todas las ramas del trabajo. "Tienen una publicación periódica, imprenta, hoteles, iglesias, talleres, clubes, abogados, médicos, maestros, como si los componentes de la colectividad se hubieran propuesto bastarse a sí mismos [...]”, decía en su libro Tres Ciclos Chaqueños ${ }^{7}$.

Los búlgaros fueron otro de los grupos con importante presencia en el Chaco, ya que entre 1923 y 1929 ingresaron 1.166 personas de ese origen. Se radicaron inicialmente en los alrededores de Sáenz Peña, pero entre 1927 y 1931 una buena parte de ellos se trasladó a la zona de Las Breñas. Una de las características destacadas de los búlgaros fue su bajo índice de analfabetismo y también el visible activismo que manifestaron durante las llamadas huelgas algodoneras de los años 1934 y 1936.

Los yugoslavos, denominación que como se sabe incluía en esta época a varias nacionalidades, se afincaron en las zonas circundantes a Sáenz Peña, Campo Largo, Corzuela, Quitilipi, Las Breñas, y Villa Angela. Llegaron a conformar una nutrida colonia en el sur de Sáenz Peña que es conocida con el nombre de "La Montenegrina"8. Los ucranianos, a su vez, se instalaron en la zona rural comprendida entre Sáenz Peña, Las Breñas, La Tigra y San Bernardo, en el centro del Chaco.

\footnotetext{
${ }^{5}$ Gobierno del Territorio Nacional del Chaco, Álbum Gráfico Descriptivo, Bs. As., 1935, p. 97.

${ }^{6}$ Beck, Hugo. "Inmigrantes Europeos en el Chaco. Transición del pluralismo al crisol”, en Cuadernos de Geohistoria... Op. Cit., p. 66.

${ }^{7}$ Miranda, Guido. Tres Ciclos Chaqueños. Crónica Histórica Regional, Resistencia-Chaco. (Argentina: Edit. Norte Argentino), 1955, p. 254

${ }^{8}$ La denominación original es "colonia José Mármol", aunque generalmente es conocida como "La Montenegrina" en virtud del origen mayoritario de sus primeros integrantes. Beck, Hugo. "Inmigrantes Europeos en el Chaco. Transición del pluralismo al crisol", en Cuadernos de Geohistoria... Op. Cit., pp. $69-70$.
} 
El grupo Germano estuvo, por su parte, representado por quienes vinieron directamente de Alemania, y los que lo hicieron desde el sur de Rusia. Dentro de los primeros, muchos se instalaron en las inmediaciones de Charata. Los segundos, llamados "alemanes del Volga" arribaron al Chaco provenientes del Territorio Nacional de La Pampa, desde donde emigraron por causa de una prolongada sequía. Ya en este Territorio poblaron las colonias "Castelli" y "La Florida" a partir de 1931, luego de un sacrificado proceso de traslado. En el siguiente cuadro pueden apreciarse las proporciones de cada nacionalidad europea arribada al Chaco entre 1920 y 1947.

Cuadro 1. Inmigrantes europeos arribados al Chaco entre 1920 y 1947.

\begin{tabular}{|c|c|l|c|c|c|}
\hline Nacionalidades & $\mathbf{1 9 2 0}$ & & $\mathbf{1 9 3 4}$ & & $\mathbf{1 9 4 7}$ \\
\hline Españoles & 2.731 & & 5.532 & & 5.220 \\
\hline Italianos & 1.411 & & 2.813 & & 2.500 \\
\hline Rusos & 205 & & 2.557 & & 3.596 \\
\hline Polacos & & & 2.095 & & 4.851 \\
\hline Checos & & & 1.628 & & 1.669 \\
\hline Yugoslavos & & & 1.484 & & 2.330 \\
\hline Alemanes & 241 & & 1.425 & & 919 \\
\hline Búlgaros & & & 1.235 & & 1.655 \\
\hline Húngaros & & & 451 & & 410 \\
\hline Austríacos & 339 & & 311 & & 660 \\
\hline Franceses & 363 & & 283 & & 222 \\
\hline Suizos & 105 & & 159 & & 162 \\
\hline Británicos & 77 & & 42 & & 32 \\
\hline Otros europeos & 308 & & 545 & & 892 \\
\hline Totales & 5.780 & & 20.560 & & 25.158 \\
\hline
\end{tabular}

Fuente: Beck, Hugo. "Inmigrantes Europeos en el Chaco. Transición del pluralismo al crisol", en Cuadernos de Geohistoria... Op. Cit., p.77, en base a los censos locales y nacionales de estos años ${ }^{9}$.

Aunque los datos del gráfico parecerían convalidar la imagen de un Chaco gringo debido a las múltiples nacionalidades presentes, insistimos en recordar que la afluencia de paraguayos y de argentinos provenientes de otras regiones del país fue muy superior a la de los europeos. Aun así, esta impresión visual es la misma que tuvieron los observadores de la época, porque en determinados lugares, la presencia más activa de colonos de origen europeo en la vida diaria hizo que los criollos fueran eclipsados, aun cuando eran mayoría.Todavía en 1955, Guido Miranda decía:

[...] a primera vista la población de ciertos lugares del Chaco parece estar compuesta exclusivamente por extranjeros [...] los que manejan carros, sulkys y tractores son generalmente europeos; los almacenes, fondas o talleres están en manos de gringos; las chacras de algodón pertenecen en su mayoría a inmigrantes o a sus hijos, quienes además de tener un extraordinario parecido físico, conservan con fidelidad el idioma y los hábitos de sus progenitores $[\ldots]^{10}$

\footnotetext{
${ }^{9}$ Cabe señalar que para estos mismos años la población total del Chaco fue de $60.564 ; 214.160$, y 430.555 habitantes respectivamente.

${ }^{10}$ Miranda, Guido. Tres Ciclos Chaqueños. Crónica... Op. Cit., p. 278.
} 
Pero esta fuerte presencia gringa producida por la intensa actividad desplegada en sus respectivos ámbitos de residencia, derivaba de muy justificables razones. Al someterse a un doloroso desarraigo ocasionado por la necesidad (o la miseria) sufridas en sus respectivos países de origen, la mayor parte de estos inmigrantes fueron obligados a revertir lo antes posible su situación en este nuevo medio. Esto solo podría hacerse mediante el trabajo febril, y es por ello que la literatura de la época los caracterizó en general como seres emprendedores y laboriosos, comportamiento que se transmitió en buena medida a sus descendientes.

En este sentido, conviene recordar algunos párrafos de las descripciones que hizo Francisco Suáiter Martínez ${ }^{11}$ sobre la mentalidad y el comportamiento del residente promedio de los Territorios Nacionales Argentinos, luego de haber observado atentamente a estos conjuntos sociales durante las primeras décadas del siglo XX. En su libro homónimo publicado en 1943, aseguraba que en los Territorios, la vida de sus habitantes giraba en torno a los valores económicos. Esos hombres y mujeres - decía- componían un ejército de trabajadores que no tenían horas para el gozo, y así terminaban formándose en un determinado tipo de hombre:

Desde sus primeros meses de vida se acunaban con el rumor del fuelle y con
la música de las máquinas agrícolas; contaban luego con pocas horas para el
juego, y aprendían a trabajar desde los primeros años. Sin niñez, desconocían
la emoción de la adolescencia; prematuramente compartían responsabilidades y
trajines, y se hacían hombres y mujeres antes de tiempo, con un carácter neutro,
casi asexuado [...] La salud no importaba demasiado; la felicidad vendría más
adelante. Primero y antes que nada había que cumplir con los requisitos de la
ley de tierras: levantar la casa, alambrar el lote, tener cultivado determinado
número de hectáreas. Una vida sin domingos era esta vida $[\ldots]^{12}$

Pero si bien esta caracterización es aplicable casi exclusivamente a las primeras etapas de la colonización en estos espacios, no deja de ser cierto que el habitante de los Territorios Nacionales se correspondía, en general, con un "tipo humano" diferente al que residía en las antiguas provincias constituidas. Algunas de esas diferencias residían, en parte, en el valor que se asignaba al "esfuerzo", que no tenía el mismo significado para los territorianos que para los provincianos.

En este sentido, Suáiter Martínez decía que mientras el provinciano no podía sostener en el tiempo el impulso inicial, la continuidad del esfuerzo, el método y la organización del trabajo; los residentes de los Territorios tenían incorporados los principios de orden, disciplina y trabajo metódico. Decía que el territoriano, al estar atado a la producción de la tierra, vivía pendiente del clima, de los precios, del futuro, y por tanto, actuaba de una manera muy particular ${ }^{13}$.

\footnotetext{
${ }^{11}$ Francisco Suáiter Martínez fue un ensayista que escribió cuatro libros entre 1937 y 1943: Patria de ayer y de hoy; Limites Argentinos (la tierra y el hombre); Buenos Aires, Ciudad y Provincia; y Los Territorios, publicado en este último año.

${ }^{12}$ Suáiter Martínez, Francisco. Los Territorios. Buenos Aires: Instituto Cultural Joaquín V. González, 1943, pp. 116-117.

${ }^{13}$ Ibid., p. 119.
} 
Y coincidiendo en muchos aspectos con Suáiter Martínez, el escritor chaqueño José Pavlotzky ${ }^{14}$ aportó en su momento su propia descripción sobre el típico inmigrante europeo instalado en el interior del Chaco: "Estos hombres de trabajo, de sencillas costumbres y de gustos aún no refinados, constituyen el fermento de la futura aristocracia del dinero y de la renta. Sin más deseo que el de prosperar económicamente, carecen de toda inquietud superior. Su único lema es hacer dinero”, decía en su descripción del habitante promedio de la localidad de Sáenz Peña ${ }^{15}$.

En la misma obra añadió otras referencias muy ilustrativas, aunque en este caso, dedicadas a la apatía espiritual que él creía ver en estos pobladores:

[...] la ciudad en ciernes (Sáenz Peña) no tiene aún su templo. Sus habitantes, por lo visto, carecen de preocupaciones espirituales. Todavía no necesitan del templo ni del sacerdote que los redima de sus pecados, y si los cometen, no afectan su tranquilidad ni el ritmo de sus negocios [...]

En este conglomerado humano de diferentes orígenes raciales y distintos cultos religiosos, los elementos no chocan sin embargo entre sí. Los une e iguala la común despreocupación por los asuntos de Dios, de los sacerdotes, de los dogmas y de los ritos. El único rito que practican con unanimidad, es el de los negocios, con la asiduidad y unción no vistos en ninguna religión $[\ldots]^{16}$

Debe, sin embargo, aclararse en este sentido, que la atención espiritual en la mayor parte del Chaco fue muy restringida hasta casi finales de la década del treinta, época en la que recién se empezó a cristalizar la organización formal de la iglesia católica. Hasta entonces, esta labor fue desempeñada por sacerdotes misioneros, de manera esporádica y con una muy acotada cobertura espacial, de modo que no podía esperarse entonces un cultivo de la espiritualidad en poblaciones heterogéneas que carecían de una instrucción religiosa regular.

\section{b) Los grupos provenientes de regiones circundantes al Chaco}

El auge del cultivo algodonero ocurrido simultáneamente con el proceso colonizador se expresó en un dinamismo extraordinario en términos económicos y demográficos. En este sentido, es necesario recordar que la explotación del textil demandó altos porcentajes de mano de obra temporal que se cubrió con los contingentes provenientes de regiones circundantes al Chaco.

Es por ello que nutridos grupos procedentes de antiguas provincias vecinas como Corrientes, Santiago, Salta o Santa Fe, participaron activamente en las tareas de

\footnotetext{
${ }^{14}$ José Pavlotzky fue un médico residente en la zona de Sáenz Peña por varios años y llegó a escribir una novela histórica titulada Esta tierra es mía, cuyo relato se basa en observaciones directas y en experiencias personales del autor en este espacio. En la obra describe las características del paisaje, los tipos sociales de la región, sus hábitos y sus costumbres. En el prólogo del libro expresa que su propósito es hacer conocer el Chaco en sus principales aspectos, y que si bien sus personajes son ficticios, los hechos que relata son reales.

${ }^{15}$ Pavlotzky, José. Esta Tierra es Mía. (Buenos Aires: El Ateneo, 1947), p. 29.

${ }^{16}$ Ibid, p. 31.
} 
Formas de integración social en un espacio en construcción. El caso del Territorio Nacional...

cultivo y zafra del algodón mediante campañas que duraban desde los meses de febrero o marzo hasta agosto o septiembre en cada año. La periódica afluencia llegó a ser muy significativa, por lo cual es necesario cuantificar y cualificar a estos grupos para dimensionar adecuadamente su incidencia en este escenario.

Solo a título ilustrativo, para 1935 los requerimientos adicionales calculados por el gobierno territorial para la cosecha de ese año hablaban de unas 30.000 personas, y en efecto, ingresaron para la zafra 29.407 braceros ${ }^{17}$. Al tener en cuenta que la población permanente del Territorio ascendía entonces a 276.343 habitantes, esta afluencia significaba elevar repentinamente en casi un $11 \%$ el número de personas residentes en el Chaco.

El movimiento que provocaba el auge algodonero ha sido cuantificado a través de registros portuarios y ferroviarios especialmente, y al margen de las diferencias que pueden discutirse, se ha estimado por ejemplo que para los años 1934, 1935 y 1936, el número de personas que "transitaron" por este Territorio fue de122.000, 165.000, y 299.000 respectivamente y en cifras redondas, es decir, en números totales de ingresos y de egresos. Por tanto, debe indicarse que en cada uno de estos movimientos periódicos siempre quedaba un remanente de personas que aquí se radicaban ${ }^{18}$.

Estos bruscos cambios demográficos provocaban naturalmente el desborde de la administración del Territorio, lo cual se evidenció de manera particular en una cierta ineficacia para ejercer un adecuado control social. Algunos de estos grupos se incrementaron anualmente y al arribar de manera aluvial desde regiones vecinas, pasaban a residir en las zonas rurales como "población flotante". Esto, desde luego, suponía informalidad laboral y precariedad en las condiciones de vida, con todo lo que ello implicaba en cuanto a sus consecuencias.

El componente medio de estos jornaleros y braceros estaba integrado, como es de suponer, por las clases más bajas de la escala social. En el caso de los braceros, aún el "profesional" de la recolección, llamado "golondrina" porque alternaba en las zafras de diferentes regiones del país, era normalmente analfabeto o semi-analfabeto ${ }^{19}$, sin instrucción adecuada respecto al conocimiento de las leyes, y cuyo respeto al orden se basaba más bien en el temor que inspiraba una autoridad visible, que al autocontrol. Eran personas curtidas, acostumbradas a las privaciones de la vida itinerante y sin hogar fijo.

\footnotetext{
${ }^{17}$ Cifras consignadas en: Gobernación del Territorio del Chaco. Memoria presentada al Ministerio del Interior por el gobernador del Territorio Nacional del Chaco, José Castells, correspondiente al año1935. (Resistencia: Ed. de la Gobernación del Chaco, 1936), p. 93.

${ }^{18}$ Por ejemplo, en el año 1936 entraron al Territorio por distintas vías 299.414 pasajeros, y salieron 267.613, quedando por lo tanto un saldo favorable de 31.801 personas en el Chaco. (Datos tomados de Castells, Jose. Memoria presentada al Ministerio del Interior por el gobernador del Territorio Nacional del Chaco, correspondiente al año1936. (Resistencia: Ed. de la Gobernación del Chaco), p. 84.

${ }^{19}$ República Argentina, Ministerio de Agricultura y Junta Nacional del Algodón. Cosecha Mecánica del Algodón. Estudio preparado por los Ingenieros Agrónomos Rafael García Mata y Rómulo Franchelli. (Buenos Aires, 1942). Según este informe "[...] el 60\% de los cosecheros era analfabeto, no habiendo pasado el tercer grado los alfabetos [...]" (Cosecha Mecánica del Algodón... Op. Cit., p. 15).
} 
La estacionalidad de las labores implicaba una vida en condiciones inestables durante el tiempo de permanencia en esta jurisdicción. Esto ocurría particularmente durante la temporada de zafra, en la que la masa de braceros arribada para tal fin que debían alternar de chacra en chacra al término de cada pasada ${ }^{20}$, sin posibilidades de permanecer en un lugar fijo, y en la mayoría de los casos, tampoco en albergues adecuados.

El periodista chaqueño Juan R. Lestani supo describir las condiciones en las que transcurría la vida cotidiana de estos trabajadores durante sus períodos de permanencia en el Chaco. Decía en 1935:

El cosechero que emigra anualmente de su provincia en número de más o menos 25.000 para el levantamiento del algodón, es una víctima de la expoliación común del trabajador. Se lo contrata por determinados precios, pero rara vez se cumple esto. Esta gente trabaja en muy malas condiciones, pues las chacras carecen de galpones de albergue para sus peones, debiendo buscar cada uno de ellos la mejor forma de afrontar las inclemencias del tiempo bajo los árboles, o en mal cubiertos techos de paja $[\ldots]^{21}$

Sin embargo, el historiador Guido Miranda ofreció otra visión sobre las motivaciones de estos grupos y de sus condiciones de permanencia al referirse a un típico movimiento de migración interna ocasionado por el proceso algodonero. Al aludir a una localidad netamente forestal del Chaco lindante con la vecina provincia de Santiago del Estero, decía:

La población de Taco Pozo es enteramente santiagueña, y cuando llega la época de la cosecha de algodón en las colonias del Este, todos sus miembros -excepto los empleados del ferrocarril- parten en masa, dejando las calles, viviendas, fondas y almacenes vacíos, como si evacuaran ante el imaginado peligro de un ataque. La zafra algodonera no les produce mayores ganancias que el trabajo en los obrajes forestales, si se calculan los gastos de tal movilización, pero responden a una profunda ansia espiritual de dichas gentes. No pueden resistir el paso de los trenes repletos de cosecheros que vienen de otras partes, o la invitación premiosa del hermano, la madre o el amigo que viajan en los ómnibus. Los coches hacinan una multitud increíble, que anticipa el mundo mágico de la zafra; días de trajín entre interminables líneas de algodón, recogiendo capullos bajo un sol ardiente, durmiendo en el suelo, comiendo en cuclillas $[\ldots]$ Parece que toda la familia estuviese penetrada de similar anhelo de trashumancia, porque se pone en viaje íntegra, con los viejos, niños, enseres, perros, la guitarra, y hasta los pájaros domésticos $[\ldots]$

A primera vista no podemos explicarnos la afición a esta vida si no es por el gusto de ambular de una chacra en otra, y por el prestigio peculiar que asumen

\footnotetext{
${ }^{20}$ Se denominaba "pasadas" a la primera o segunda recolección de los capullos durante cada temporada. En esta época, por lo general se usaban dos "pasadas", entre las cuales, los braceros se iban a otra chacra hasta que se abrieran los capullos secundarios de la anterior.

${ }^{21}$ Lestani, Juan Ramón. El Territorio Nacional del Chaco. Geográfico, Económico, Social. (Oro y Miseria) (Resistencia: S/Ed, 1935), pp. 36-37.
} 
Formas de integración social en un espacio en construcción. El caso del Territorio Nacional...

en sus almas las reuniones que durante la noche se realizan a campo abierto, con música, juegos y recuerdos de otras cosechas, en las que se entremezcla una desprejuiciada libertad de temas y maneras $[\ldots]^{22}$

Otro informe referencial sobre las condiciones laborales y de vida de los cosecheros que arribaban al Chaco en esta época, fue el que confeccionaron los ingenieros agrónomos Rafael García Mata y Rómulo Franchelli, quienes en su función de representantes de la Junta Nacional del Algodón ${ }^{23}$ hicieron entre 1939 y 1941 una precisa evaluación de estas cuestiones para demostrar las ventajas que reportaría la mecanización de la cosecha algodonera, con el fin de resolver, entre otras cosas, la problemática humana devenida de las tareas manuales de zafra.

En el informe se definieron a la masa de cosecheros inmigrantes de otras provincias como la mano de obra adventicia, la cual, si bien reconocían que aportaba un valioso recurso para la zafra, “[...] dicha solución estaba lejos de satisfacer las más elementales exigencias de la dignidad humana" ${ }^{24}$. La postura de los autores a lo largo de su informe, fue que la mecanización de la cosecha evitaría la explotación del bracero, "[...] germen permanente de disturbios sociales como consecuencia de su lamentable situación económica"25.

En el mismo se explayaron acerca de las condiciones de vida de estos cosecheros y advirtieron desde un principio que "[...] nada nuevo se agregaría si se afirma que sus condiciones de vida durante su estadía son muy precarias" ${ }^{\prime 2}$. Sobre el alojamiento de los grupos, aclararon que no todos los agricultores disponían de espacios aptos para ese fin, por lo que era habitual la construcción de viviendas muy rudimentarias, por parte de los propios braceros. Las fotografías con que ilustraron el tema, son en tal sentido muy representativas. Además, las referencias adicionales ofrecen caracterizaciones de las diferentes particularidades de los cosecheros correntinos y santiagueños respectivamente, los que a la sazón, integraron los grupos mayoritarios de esta masa laboral y cuya periódica afluencia marcó una fuerte impronta en la conformación identitaria de la sociedad chaqueña.

Al respecto, señalaron que la idiosincrasia del bracero correntino difería por completo de la del santiagueño, ya que, por ejemplo, los primeros se dirigían a la cosecha del algodón más por costumbre o por tradición que para obtener un beneficio económico.

También, procuraron demostrar sus argumentos al explicar que cuando se realizaba alguna fiesta, ya fuese religiosa o de otro carácter, en sus lugares de origen, los correntinos concurrían a las mismas para regresar luego a la cosecha, aún con todos

\footnotetext{
${ }^{22}$ Miranda, Guido. Tres Ciclos Chaqueños. Crónica ... Op. Cit., p. 57.

${ }^{23}$ La Junta Nacional del Algodón fue creada en 1935.

${ }^{24}$ República Argentina, Ministerio de Agricultura y Junta Nacional del Algodón. Cosecha Mecánica ... Op. Cit., p. 11.

${ }^{25}$ Ibid., p. 12.

${ }^{26}$ Ibid., p. 15.
} 
los gastos y la pérdida de días de trabajo que esto les suponía. Otro ejemplo que usaron para justificar esta afirmación fue el hecho de que, según sus observaciones, al término de la cosecha los correntinos retornaban a sus "Pagos" sin llevar un solo centavo de lo ganado.

En cambio el santiagueño -indicaban- es mucho más interesado y trata en todo momento de reunir la mayor cantidad de dinero posible, aún a costa de su propia comodidad. Dicen haber comprobado, incluso, en el caso de familias santiagueñas que con lo ganado en la cosecha en el Chaco, habían podido construir su casa en sus lugares de origen $^{27}$. Naturalmente, las zonas en las que con preferencia se concentraban los correntinos eran desde el Este del Chaco (próxima a Corrientes) hasta las inmediaciones de Sáenz Peña (centro), mientras que los santiagueños se distribuían desde este punto hacia el sud-oeste. A su vez, desde Sáenz Peña hacia el norte, la zona algodonera vinculada a las localidades de Pampa del Infierno y Concepción del Bermejo, era atendida por cosecheros golondrina que venían de las provincias de Salta y Tucumán ${ }^{28}$.

Desde luego, estos contingentes trajeron consigo el acervo cultural propio e identificativo de sus lugares de origen, y hasta sus tipologías físicas particulares, y esos aportes se incorporaron al mosaico multicultural en que se estaba transformando el Chaco.

\section{Los primeros ámbitos de vinculación social en los espacios receptores de la segunda corriente inmigratoria}

Durante los primeros años de residencia en este Territorio la mayor parte de los inmigrantes europeos estuvieron consagrados a revertir sus apremiantes necesidades materiales y a consolidar las posiciones obtenidas en una determinada actividad u oficio. Satisfechas estas urgencias, que no demandaron más de cinco años en el contexto próspero del Chaco de los años veinte, se dispuso de más tiempo (y recursos) para destinarlos a las sencillas formas de sociabilidad que comenzaron a practicarse en esta sociedad en formación, y que fueron lógicamente, uno de los mecanismos que propiciaron la integración.

En los primeros tiempos la interrelación social, este proceso de incorporación estuvo más o menos reducido al propio grupo étnico, práctica que mantuvo una mayor perdurabilidad entre los eslavos y germanos especialmente. Esto puede constatarse en parte, al analizar las pautas matrimoniales que en algunas colectividades reflejaron, por ejemplo, altos índices de endogamia. Pero, luego comenzaron a surgir los primeros espacios de sociabilidad multiétnicos que posibilitaron un

\footnotetext{
${ }^{27}$ Ibid., p. 13.

${ }^{28}$ Se llamaba cosecheros golondrina a los que, con sus respectivas familias, migraban de una región a otra durante las temporadas de zafra. Por ejemplo, era habitual que estas familias (incluyendo los niños) trabajaran en la vendimia de la región de cuyo, para pasar luego a la carpida de algodón en el Chaco; trasladarse posteriormente a la zafra de la caña de azúcar en la provincia de Tucumán, para retornar nuevamente al Chaco a la cosecha algodonera, que se extendía hasta el mes agosto. Al año siguiente, recomenzaban el ciclo.
} 
contacto más fluido entre los diversos grupos de origen europeo y sobre todo entre estos y los inmigrantes internos (criollos). Estos ámbitos fueron en principio las asociaciones mutualistas y las cooperativas agrícolas que actuaron como canales de contacto entre las familias y entre centros inmejorables para el ejercicio de la vinculación social.

Las sociedades mutualistas fueron las primeras organizaciones que posibilitaron estos intercambios en el Chaco, y a la sazón, varias de ellas se fundaron tempranamente en este Territorio Nacional. Tal vez esté de más señalar que entre las primeras entidades de este tipo, surgidas en el Chaco, estuvieron las de los italianos y españoles, por ser las colectividades mayoritarias afincadas durante la primera etapa inmigratoria. Sin embargo, durante la segunda corriente, y particularmente en la zona central del Chaco, una de las primeras instituciones fundadas y vinculadas esta vez a los nuevos grupos arribados; fue la de los checoslovacos, constituida en Sáenz Peña bajo el nombre de Slavia en el año 1917. Luego surgirían otras como la Unión Germánica, en Charata (1920); la Sociedad Húngara de Cultura y Socorros Mutuos, en Villa Angela (1931). Otros centros culturales y de beneficencia fueron, por ejemplo, los que se erigieron en la colonia La Montenegrina en 1927, o la de los Búlgaro Macedónicos en 1929 en Las Breñas. Posteriormente nacerían las asociaciones pertenecientes a los búlgaros y los yugoslavos, ambas en Sáenz Peña, aunque lo harían tardíamente, ya en la década del cincuenta. Estas instituciones cumplieron cabalmente con el propósito para el cual fueron creadas, y en general, tuvieron una política de puertas abiertas hacia quienes no eran parte de la colectividad respectiva.

En lo que respecta a las cooperativas agrícolas, las primeras instituciones de este tipo surgieron en el Chaco en su zona oriental, como consecuencia de la acción de los pioneros de la primera corriente inmigratoria. Ya en la segunda etapa de afluencia y en buena medida como parte del auge algodonero, se expandirían en la zona central y sudoeste del Territorio. A partir de 1925 se multiplicaron estas entidades hasta llegar a 16 en 1934; 24 en 1940, y 32 a finales de esa década. En un alto porcentaje se instalaron en los departamentos que concentraron en este momento el mayor volumen de la masa inmigratoria, es decir, Campo del Cielo y Napalpí, y como era de esperar, dichas instituciones llegaron a asociar al 75\% de los agricultores, e incluyeron -sin distinción- a criollos e inmigrantes de diferentes orígenes ${ }^{29}$.

Además de las funciones específicas de proteger los intereses de sus asociados, estas cooperativas actuaron como centros vinculantes de la masa social ligada a ellas. Por haber conocido esta realidad in situ, creemos estar en condiciones de respaldar enteramente la descripción que hiciera el historiador chaqueño Guido Miranda al referirse, por ejemplo, al evento excepcional que representaban las asambleas anuales de estas entidades, las que por sus características fueron un inmejorable espacio de vinculación social entre grupos que normalmente no tenían muchas posibilidades de contacto, sobre todo a nivel familiar. Decía Miranda:

\footnotetext{
${ }_{29}$ Datos tomados de Beck, Hugo. Beck, Hugo. "Inmigrantes Europeos en el Chaco. Transición del pluralismo al crisol”, en Cuadernos de Geohistoria... Op. Cit., p. 112.
} 
Hay un día en el año en que se paralizan los trabajos en las chacras; toda la familia, inclusive los peones, se acicala con la mejor vestimenta y parte -en carros, sulkys o volantas- para asistir a un acto que tiene lugar en el pueblo, y que dura desde la mañana hasta altas horas de la noche: es la Asamblea Anual Ordinaria de la Cooperativa. Siempre hemos contemplado con emoción estas vastas asambleas públicas, celebradas en los galpones de zinc que sirven para almacenar la fibra o la semilla de algodón. Son un acontecimiento característico del Chaco: cientos de socios de la más heterogénea condición [...]; agricultores, viejos, hijos, o viudas que siguen con la labor, se reúnen a discutir intereses comunes a pesar de las diferencias de idioma, origen, situación, educación, o temperamento $[\ldots]^{30}$

Finalizada la reunión, lo cual solía ocurrir pasado el mediodía, se procedía a servir el tradicional asado vacuno a una verdadera multitud, ya que en este agasajo participaban muchos lugareños, aunque no fuesen socios de la cooperativa.

Infinitas hileras de mesas y de bancos improvisados con tablones; manteles hechos con "papel madera" apretujaban a cientos de comensales atendidos por voluntarios organizados espontáneamente. Un caótico trajín de bandejas con grandes trozos de carne; palanganas conteniendo ensaladas, y abundante vino común de Damajuana, animaban los espíritus. Algarabía; conversaciones destempladas; representaciones espontáneas que permitían desplegar dotes artísticas desconocidas en los participantes, y el bullicio de los niños jugando, amenizaban el banquete hasta que llegaba el infaltable sorteo de la "rifa", y finalmente, el baile popular cuando caía la tarde. Este era el típico transcurso de una asamblea ordinaria en cualquier cooperativa del Chaco, al menos, hasta la década del setenta. ${ }^{31}$

De esta forma, además de la función específica que cumplieron estas asociaciones, indudablemente desempeñaron un rol, no menos importante, como centros de interrelación cultural y social en ámbitos en los cuales los puntos de contacto colectivo no abundaron. En estos espacios llegaron a forjarse sólidas amistades entre criollos y gringos, y con frecuencia, fueron también el entorno ideal para propiciar el nacimiento de lazos parentales derivados de las relaciones entabladas entre las nuevas generaciones.

\section{Los espacios y las formas de sociabilidad en los núcleos urbanos}

Como hemos dicho, en el Chaco de los años veinte en adelante existieron zonas en las que sobresalió con mayor relevancia la actividad algodonera, lo cual potenció la prosperidad de localidades y colonias vinculadas a la misma para atraer, de esta forma, a la mayor parte de los contingentes que vinieron a participar del exitoso proceso algodonero. Este fenómeno pudo observarse con particular claridad en el departamento denominado "Napalpí", en el centro geográfico del Territorio, cuya

\footnotetext{
${ }^{30}$ Miranda, Guido. Tres Ciclos Chaqueños. Crónica... Op. Cit., pp. 259-260.

${ }^{31}$ Este relato se basa en las experiencias vividas de quien suscribe al asistir frecuentemente a estas reuniones en distintas cooperativas agrícolas del sudoeste del Chaco.
} 
cabecera era la ciudad de Sáenz Peña, fundada en 1912, y que conserva hasta hoy el segundo lugar en orden de importancia en el Chaco.

Esta actividad puede tomarse como la muestra más representativa del conglomerado multiétnico asentado en el interior del Chaco, y por ello consideramos que la descripción de la vida cotidiana de sus habitantes y de sus maneras habituales de interrelación, nos ilustra en buena medida sobre lo ocurrido en otros pueblos del Territorio. En este sentido, son muy útiles las referencias proporcionadas por los lugareños y la información procedente de los periódicos locales.

Durante las décadas del veinte y hasta finales de la del cuarenta, Sáenz Peña y sus adyacencias fueron prácticamente el centro dinámico de producción del Chaco, donde el crecimiento poblacional marchó a un ritmo concordante. Solo basta decir, por ejemplo, que el departamento Napalpí, cuya cabecera era precisamente esta ciudad, pasó de 5.552 habitantes en 1920 a 50.652 en $1934^{32}$. En 1935 su población estrictamente urbana era ya de 14.899 personas y en 1940 alcanzaba a 25.513 habitantes, de manera que en muy pocos años esta ciudad multiplicó su población considerablemente. Su cuerpo social fue muy heterogéneo, por lo cual su imagen a finales de los años veinte era la de una ciudad cosmopolita en donde el trajín multiétnico dominaba la escena ${ }^{33}$.

Pero al margen de su agitado ritmo de vida, esta comunidad afrontaba algunas dificultades propias de su sitio de emplazamiento, a causa de la infraestructura, y desde luego, del vertiginoso crecimiento demográfico ocasionado por el auge algodonero en el Chaco. Durante esta década, todo estaba aún por hacerse u organizarse en una ciudad que no llegaba a cumplir quince años desde su fundación.

Por ello, sus residentes procuraban subsanar algunas de las carencias con los mecanismos a su alcance, especialmente a través de la acción de asociaciones civiles que se constituían -a veces espontáneamente- para impulsar iniciativas o cubrir servicios que los organismos del Estado, por ineficacia o distancia, no alcanzaban a satisfacer.

Precisamente, estas acciones grupales contribuían indirectamente a desarrollar vínculos sociales mediante la participación común en actividades de recreación y esparcimiento orientadas, por lo general, a la recaudación de fondos para obras de bien

\footnotetext{
${ }^{32}$ Cifras consignadas por los censos territoriales del Chaco correspondientes a dichos años. Citado por Borrini, Héctor. "La Colonización como Fundamento de la Organización Territorial del Chaco (19301953)", en Cuadernos de Geohistoria Regional, n. ${ }^{\circ} 19$. Resistencia, IIGHI-CONICET, 1987, p. 80.

33 [...] Las calles se atestan de camiones, volantas, sulkys, caballos en los alrededores del Banco, las cooperativas y las casas de ramos generales. Los carruajes deben colocarse en varias hileras, entre las cuales han de moverse con prolijidad de hormigas por imperceptibles hilillos de espacio. En las fondas, una humareda olorosa de frituras, tabaco y alcohol se mezcla con el tumulto de voces, fanfarronadas, risas y pendencias, como en las posadas de madera del Far-West cinematográfico [...] Los almacenes y las tiendas deben cerrar sus puertas varias veces al día, para atender la clientela que en ciertos momentos colma las dependencias, y renovar de hora en hora el público [...], recuerda el historiador chaqueño Guido Miranda, que a la sazón, fue uno de los testigos presenciales de los efectos del auge algodonero en el Chaco, y especialmente, de la vida cotidiana en esta última ciudad. (Miranda, Guido. Tres Ciclos Chaqueños. Crónica... Op. Cit., p. 253).
} 
público. En ésta época fue muy frecuente, por ejemplo, la organización de romerías y bailes para construir instalaciones deportivas, sanitarias, o de seguridad; y al tener la recaudación un destino comunitario, se publicaban sus resultados en los periódicos locales. Ello nos permite conocer hoy entre otras cosas, algunas modalidades de sociabilidad o entretenimiento de los parroquianos.

Pero independientemente de estas reuniones que tenían una finalidad prioritariamente recaudatoria, nuevas oportunidades de vinculación surgían en las conmemoraciones patrióticas que ya comenzaban a hacerse más participativas y tenían un efecto aglutinante en esta heterogénea sociedad. Por ejemplo el "Día del trabajo"; el 25 de mayo, o el 12 de octubre entre otras fechas, daban ocasión para lograr un triple propósito: estrechar vínculos; divertirse, y al mismo tiempo, recaudar fondos para fines comunes ${ }^{34}$.

En ocasión de fiesta popular o patria se ampliaba la práctica de actividades recreativas. Así, por ejemplo, en un primero de mayo corriente se hacían los actos correspondientes en la plaza, en donde luego de las alocuciones inherentes se entonaba el himno al trabajo para concluir la mañana con la protagónica intervención de alguna colectividad pre-seleccionada, como la checoslovaca por ejemplo, que desplegaba su música y danzas típicas ${ }^{35}$.

Era costumbre continuar la agenda en algún campo cercano, en donde se montaban los buffets, y se ponían en práctica los juegos deportivos y de azar. Por la noche era usual que los festejos continuaran con una velada en el teatro (que ya poseía la ciudad), en donde sin imponerse distinciones de clases - dada la fecha -, se ofrecía la proyección de una película nacional ${ }^{36}$. Los fuegos artificiales de medianoche concluían con las celebraciones de la jornada ${ }^{37}$.

Del mismo modo, la conmemoración de un venticinco de mayo ${ }^{38}$, liderada en este caso por otra colectividad, como la italiana por ejemplo, comenzaba el venticuatro a la noche con una velada en la Sociedad Italiana de Socorros Mutuos, en la que además del himno nacional y la Marcha Italiana, se ponían en escena otros números musicales vinculantes $^{39}$. El 25 a la mañana después de los actos y del almuerzo, se realizaban los juegos deportivos que tenían como atracción central, la disputa futbolística entre solteros contra casados, práctica muy vigente por entonces.

\footnotetext{
34 Algunas descripciones expuestas en este apartado han sido publicadas como parte de un artículo de nuestra autoría titulado: "Interrelación, costumbres y entretenimientos en espacios representativos del Chaco Austral argentino durante la etapa territoriana", en Revista Amerika, LIRA, Université Renes, Francia, n. ${ }^{\circ}$ 9, 2013, http://amerika.revues.org/4094.

${ }^{35}$ La orquesta de esta colectividad era la de la sociedad Slavia que agrupaba a los checoslovacos.

${ }^{36}$ Por ejemplo, para el año que estamos refiriendo (1926), la película proyectada fue "La casa de los cuervos".

${ }^{37}$ Una más amplia descripción de esta celebración puede apreciarse en el periódico El Imparcial, de Sáenz Peña, en sus apariciones del 28 de abril y 5 de mayo de 1926.

${ }^{38}$ En Argentina, el 25 de mayo recuerda la revolución emancipadora y la asunción del primer gobierno patrio, ocurridos en 1810 .

${ }^{39}$ Tales como: "La Argentina te llora"; "La familia de sordos"; el "Dúo de la africana", y otros.
} 
Por otra parte, una fiesta típica de un "Doce de Octubre"40, revestía caracteres más pintorescos, ya que normalmente era organizada por la Sociedad Española. Además de los actos esperables para la fecha, el número principal se desarrollaba en el teatro local con números estrechamente asociados a la cultura de esta colectividad ${ }^{41}$. Durante el día se incluía en los festejos a los pobladores de la cercana localidad de Quitilipi y colonias adyacentes, y a los juegos populares desarrollados que consistían en el "football" (como se escribía entonces); el "box"; las carreras de sortijas; de bicicletas; de caballos; las "domas" de potros y novillos; y por la noche, se concluía con los "concursos" de baile ${ }^{42}$.

Además de estas fiestas anuales, un regular hábito de esparcimiento de los lugareños consistía en asistir los fines de semana a las retretas que se realizaban en la plaza central, en donde por lo general, actuaba la banda municipal. Al día siguiente se publicaban los comentarios en el periódico, en el cual se daban minuciosos detalles del evento ${ }^{43}$.

Dentro de estas incipientes prácticas de vinculación social en una comunidad hasta entonces habituada al esfuerzo constante, y en un momento en que la prosperidad parecía consolidarse como consecuencia de los altos precios del algodón, surgió también la posibilidad de ensayar nuevas prácticas sociales que procuraron emular las imágenes ofrecidas por el cine (ocasionalmente presente en Sáenz Peña), o por la publicidad de los periódicos. Fueron precisamente estos dos medios los que indujeron una nueva gestualidad, modas, y formas de sociabilidad que los habitantes de esta comuna buscaron adoptar para mejorar su trato social. En los periódicos locales podían verse, por ejemplo, avisos publicitarios de sastrerías que promovían mediante extensos mensajes de tono didáctico, la compra de artículos indumentarios equiparándolos a "armas de lucha" imprescindibles para el logro de la aceptación pública ${ }^{44}$.

\footnotetext{
${ }^{40}$ El 12 de octubre se celebra en Argentina el "Día del respeto a la diversidad cultural”, conmemorando el descubrimiento de América.

${ }^{41}$ En este año actuó la "Compañía de Zarzuelas y revistas de Pepe Otero". (El Imparcial, Sáenz Peña, octubre 13 de 1926).

42 El Imparcial, Sáenz Peña, octubre 13 de 1926.

${ }^{43}$ Por ejemplo en un número del año 1926, se comentaba: [...] como pocas veces se vio concurrida nuestra plaza el último domingo; era un ir y venir de airosas y atrayentes siluetas femeniles [sic], sorprendiendo más de una sonrisa picaresca, o sintiendo nuestro oído la caricia del eco simpático de una alegre carcajada que irrumpía ante la oportunidad de un chiste o un piropo halagador [...] La afluencia del sexo opuesto fue considerable, pudiéndose notar cantidad de rostros nuevos, y hasta se ha semejado nuestra pequeña retreta a la de una ciudad populosa, pues no escasearon las frases elegantes y las miraditas lánguidas, cosa no muy común en estos lugares... Entre las familias que prestaron realce a nuestro paseo, anotamos las de [...] (y se enumeran...). (El Imparcial, Sáenz Peña, abril 28 de 1926).

${ }^{44}$ Un aviso auspiciado por un sastre de apellido Colella, decía: [...] El carácter de las personas se forma conforme a las fuerzas determinantes que lo hayan modelado: hogar, escuela, medios de vida, etc. En ello influye mucho el traje que vista. Si está mal confeccionado, la conciencia se preocupa por el sentimiento desfavorable que causará en los demás, y el afecto moral es deprimente. En cambio si es elegante, amén de provocar la admiración, se siente la satisfacción del triunfo, y esto crea el espíritu[...] (El Imparcial, febrero 17 de 1926).
} 
De todos modos, debe aclararse que en el habitante promedio de esta y de buena parte de las comunidades receptoras de inmigración en el Chaco, esta incipiente inclinación a socializar no fue -al menos en esta época- una necesidad afectiva, sino más bien un recurso para consolidar o acrecentar relaciones en función de un objetivo esencialmente utilitario, tal como lo ha deslizado Pavlotzky en sus descripciones ${ }^{45}$.

\title{
Los lugares y las formas de interrelación social en los espacios periurbanos $y$ rurales
}

\begin{abstract}
Ahora bien, otros ámbitos tuvieron sus propias peculiaridades en cuanto a las formas de vinculación social, y estos son los que podríamos denominar periurbanos por un lado, y los netamente rurales, por otro. Estas subdivisiones que nos permitimos hacer funcionan solo para señalar algunas particularidades, pero a sabiendas de que en esta época era difícil marcar una clara distinción de comportamiento entre el habitante rural y el urbano, porque sus vidas transcurrían de manera similar y en una estrecha relación, ya que las colonias no se hallaban muy distantes de los pueblos. En ambos mundos, casi todo estaba asociado a la producción del campo, y en cualquier caso, las diferencias que podrían establecerse serían las posibilidades de vinculación que disponían en uno u otro ámbito.
\end{abstract}

Es que no podía haber en esta jurisdicción recientemente colonizada una distinción de "clases". Al ser un espacio nuevo, no existían tradiciones ni linajes, y además, la inmensa mayoría de los pobladores, ya fuesen europeos o criollos, venían de un pasado inmediato de pobreza o de privaciones. Ello obligaba a compartir ámbitos comunes de sociabilidad sin separaciones excluyentes, aunque en ciertos casos, ya comenzaban a insinuarse algunas medidas que procuraban delinear sutiles jerarquizaciones. Este es precisamente el ejemplo representativo que intenta transmitir Pavlotzky cuando describe un típico baile popular en la periferia de Sáenz Peña durante la década del cuarenta. Al referirse a las características de uno de estos eventos organizado a beneficio de la construcción de una sede policial, este lugareño nos cuenta:

[...] hombres, mujeres y niños del pueblo se agrupan junto a un alambrado y desde allí contemplan el espectáculo que se desarrolla del otro lado, donde en un palco levantado en el centro, una orquesta del lugar inicia los acordes de un tango. Salen las parejas y se ve que hay dos pistas de baile separadas por un alambrado. En una, de piso de mosaico, hay mesitas y sillas ubicadas en la periferia del cuadrado, donde gente bien vestida bebe, conversa, ríe y salen a bailar al son de la orquesta $[\ldots]^{46}$

\footnotetext{
${ }^{45}$ Sugerimos los comentarios realizados por Pavlotzky, José. Esta Tierra ... Op. Cit. sobre los residentes del ámbito Sáenzpeñense.

${ }^{46}$ Y agregaba: [...] Es el baile que organiza la Comisión Popular Pro-Edificio Policial, todas las noches, para recaudar fondos. La comisaría de esta ciudad se halla en un ruinoso edificio alquilado, sin calabozos y con escasas oficinas, y los presos se escapan vuelta a vuelta por el baldío que la circunda. El comisario tiene que recurrir a todo su ingenio para mantenerlos a disposición de la justicia, y para ello no ha tenido más remedio que volver a ciertas prácticas ya olvidadas, como la de los "grillos". El espectáculo de los presos engrillados por los pies a la vista del público (el patio de la comisaría tiene sólo un alambrado), es deprimente, y hace recordar épocas ya superadas en nuestro país. Por ello el vecindario colabora para construir la comisaría,
} 
Formas de integración social en un espacio en construcción. El caso del Territorio Nacional...

La otra pista, de tierra regada, está recuadrada por largos tablones que descansan sobre cajones y sirven de asiento a las parejas sencillas. Los hombres visten bombachas y blusas; otros, pantalón y camisa; y las mujeres, vestidos simples de percal de fuertes colores $[\ldots]$

En una y otra pista, dos buffetes [sic] improvisados en casillas de madera expenden las bebidas que sirven los mozos trajeados con blancas blusas. Cada pista tiene su entrada por separado, en las que miembros de la Comisión venden los boletos y controlan el ingreso del público. En la pista "popular" llama la atención la presencia de agentes de policía uniformados y de guardia, como si se tratara de presos entre los que hay que guardar el orden. En la otra pista, en cambio, no hay tal vigilancia $[\ldots]$

La ciudad en formación está estructurando sus clases sociales que marcan, por ahora, esta división de pistas para bailar. De un lado, está la pequeña burguesía (todavía no hay gran burguesía) comerciantes, industriales, funcionarios, y algún que otro chacarero ya enriquecido. Del otro, el proletariado: el peón, el obrero de la fábrica, el cosechero, el hachero. Todos vienen a divertirse, a distraerse. Distintas vidas, distintos problemas, pero los mismos deseos de olvidarlos. Y mientras la popular se llena de parejas bailando tangos y polkas paraguayas, en la otra tiene más éxito el fox; diferencia de clases, diferencia de gustos $[\ldots]^{47}$

Ahora, ¿cómo funcionaba la interacción social en aquellos lugares en los que aún no se habían organizado entidades o asociaciones que pudieran cumplir, aunque fuese secundariamente con este propósito?

Estamos pensando fundamentalmente en los ámbitos netamente rurales, a los que periódicamente confluían miles de trabajadores temporarios para participar de tareas estacionales y que en determinadas ocasiones, precisaban momentos de distracción, esparcimiento, y posibilidades de vinculación social.

En estos casos debemos anticipar que la vinculación social se caracterizó esencialmente por una cierta espontaneidad, tanto en la selección de los espacios, como en lo referido a las prácticas de sociabilidad.Por ejemplo, la interrelación en el campo se daba generalmente en parajes ubicados en las intersecciones de los caminos vecinales bien conocidos por los lugareños, en donde a menudo había un núcleo de "ranchos" o "boliches" que oficiaban de centros proveedores de servicios, de puntos de encuentro, y consecuentemente también, de ámbitos de sociabilidad.

En las eventuales reuniones participaban todos los componentes de ese mundo (colonos "gringos", propietarios y capataces de obrajes forestales, jornaleros, cosecheros y/o peones), sin ningún tipo de prejuicios discriminatorios.

ya que el gobierno no se preocupa por éste, ni muchos otros problemas [...] (Pavlotzky, José. Esta Tierra... Op. Cit., pp. 38-41)

${ }^{47}$ Ibid. 
En ocasión de fiesta o de celebración, por lo general la jornada se desarrollaba de la siguiente forma: durante el transcurso del día se jugaban campeonatos de "truco"; "bochas", "taba", o a la "lotería"; y ya desde la década del veinte, también el "football" con un rudimentario amateurismo que derivó en los clásicos y pintorescos enfrentamientos entre equipos de "casados" contra "solteros", práctica que se conserva hasta hoy en los espacios rurales del Chaco, al igual que los premios: una vaquilla para el primero, y cajones de vino o cerveza para el segundo. Las carreras de caballos (cuadreras) estaban casi siempre incluidas, aunque la sortija ecuestre, la doma de potros, las competencias de "embolsados", o la subida al "palo enjabonado", generalmente quedaban reservadas para las festividades patrias.

Por la noche se hacía el baile, casi siempre basado en la música derivada del folklore litoraleño y animado por "musiqueros" aficionados del lugar. Polkas correntinas y paraguayas eran por lo general las piezas más requeridas, ya que posibilitaban la danza entrelazada; valseados y pasodobles completaban las demandas, siempre que los tríos o cuartetos formados casi espontáneamente, los tuvieran entre sus repertorios. La música folklórica "santiagueña" se escuchaba también asiduamente, interpretada casi instintivamente por cualquier migrante oriundo de esa provincia, pero no se usaba para la danza en estas "bailantas".

Sin embargo, es necesario destacar que habitualmente estas jornadas casi nunca finalizaban libres de incidentes. La discrecional circulación de bebidas fermentadas o destiladas; la rusticidad del componente social involucrado, y la insuficiente o nula vigilancia policial, propiciaban las trifulcas propias de este tipo de eventos, siendo también bastante frecuente que desembocaran en lesiones graves $u$ homicidios ${ }^{48}$

\footnotetext{
${ }^{48}$ La libre portación de armas constituyó el principal factor desencadenante de hechos de sangre, a tal punto que en las estadísticas oficiales, entre las principales causas de muerte por motivos constatables, figuran en primer lugar la bronconeumonía, seguida de la tuberculosis; en tercer lugar, la muerte producida por armas de fuego, y en quinto lugar, la producida por heridas de arma blanca. (Castells, Memorias correspondientes a los años 1934, p. 150; 1935, p. 50-51; y 1936, p.77)

El gobernador José Castells (1933-1938) se propuso limitar el derecho de portar armas, por cuanto entendía que para los tiempos que corrían eran innecesarias las licencias que concedía el Código Rural, y estaba probado que esto implicaba excesos que terminaban casi siempre en hechos de sangre. (AHPCH, Copiadores de la secretaría de la gobernación del Chaco. Gobernador José Castells, enero 26 de 1934). Además, este gobernador se concentró en otro punto que consistía en tratar de prevenir los desórdenes y las riñas en el interior del Territorio, si tener que aumentar por ello los recursos policiales. Desde años anteriores se observaba en las estadísticas que casi la totalidad de las peleas y homicidios se producían los sábados en los boliches y bailes del interior, especialmente como consecuencia del desenfreno en el consumo de bebidas alcohólicas. Por ello, se puso en marcha una campaña en donde se impondría el sistema del "Sábado Inglés", por el cual se prohibía la apertura de locales ese día, como también el expendio de bebidas alcohólicas en Kermeses, bailes y clubes. Estas medidas se complementaban además con la prohibición de carreras de caballos, riñas de gallos, juegos de taba y naipes. Pero esto no podía ser más que una buena intención, sencillamente porque el Chaco no contaba con infraestructura policial para ejercer estos controles, y porque además, los mismos agentes transgredían las normas, como puede comprobarse en la documentación oficial y periódicos de la época. (Para ampliar sobre este tema: AHPCH, Copiadores de la secretaría de la gobernación, Gobernador Castells, diciembre 1 de 1933, p.113, y en extenso: Mari, Oscar Ernesto. "La transición entre dos ciclos y sus efectos sociales en un territorio argentino. Conflictos de convivencia en Chaco ante una nueva etapa colonizadora 1920-1940", en Revista de Geografía Norte Grande, n. ${ }^{\circ}$ 42, Universidad Católica de Chile, 2009, pp. 21-40.
} 
En este sentido debe decirse que el tema de la inseguridad en el ámbito rural del Chaco en esta época es suficientemente conocido en la historiografía regional y no es posible de abordar su desarrollo en este artículo, pero en cualquier caso debe tenerse en cuenta que su causa obedeció a múltiples factores, de los cuales una buena parte son adjudicables a la propia efervescencia de la colonización y del auge algodonero ${ }^{49}$

De todos modos, y aún dentro de las lógicas limitaciones del ámbito rural en lo concerniente a los espacios de sociabilidad, debe señalarse que la integración entre los diferentes conjuntos sociales que lo poblaron no tuvo mayores restricciones y se produjo casi de manera natural en un medio despojado de prejuicios, donde el mutualismo y la colaboración recíproca fueron más redituables que la imposición de formas de distinción o jerarquización.

\section{Algunas reflexiones finales}

Al iniciar este trabajo y durante su desarrollo nos hemos preguntado si era correcto emplear la palabra "integración” para definir el comportamiento de los grupos foráneos que participaron en el proceso vinculado a la colonización y al auge algodonero en el Chaco. Teníamos dudas respecto a generalizar la implementación del término a un conjunto social tan heterogéneo y arribado aluvialmente, como fue el que pobló el espacio interior de este Territorio.

De hecho, contábamos con la opción de acudir a otros términos de contenido más relativo, como "articulación", "coexistencia", o "convivencia", por ejemplo, porque en determinados momentos y lugares, éstos podían ajustarse mejor al tipo de relación establecida entre los diferentes grupos sociales que se afincaron en el Chaco. Pero, en cualquiera de los casos, notábamos que más temprano que tarde terminaríamos hablando finalmente de "integración", porque este es precisamente el fenómeno que comenzó a gestarse en el Chaco de esta época; integración que por otra parte, no fue únicamente social, sino también del hombre con el medio, con la tierra que eligió adoptar.

Ahora, esta integración fue indudablemente facilitada por el escenario y el momento en que se produjo un espacio nuevo, de reciente ocupación, sin tradiciones ni linajes que condicionaran las relaciones humanas. Aún así, este proceso no se dio con la misma fluidez en todas las situaciones. Influyó en ello la idiosincrasia particular de cada grupo, y también el lugar de residencia, según fuese este rural o urbano.

El tiempo de adaptación varió según la procedencia del grupo inmigratorio. Dentro de los europeos, los de origen latino fueron quienes lograron una inserción más rápida y sin mayores traumas. Sin embargo, esto les llevó algo más de esfuerzo a los eslavos y germanos.

\footnotetext{
${ }^{49}$ Sobre el tema de la inseguridad rural en el Chaco en esta época, hemos publicado un libro titulado Inseguridad y bandidaje en el territorio nacional del Chaco 1917-1940, IIGHI-CONICET, 1994, y varios artículos que están disponibles online.
} 
Por su parte, los inmigrantes internos, fundamentalmente los provenientes de las regiones circundantes al Chaco, fueron quienes menos padecieron el proceso de adaptación cuando decidieron afincarse. No solo concurrieron con entusiasmo sino que la perspectiva de arraigar les representó un aliciente adicional, una nueva oportunidad para sus vidas. Estos grupos, particularmente los correntinos y santiagueños, tendrían una fuerte influencia en la transmisión de sus pautas culturales a esta sociedad en formación.

Si bien el mundo laboral fue generalmente el propicio para la integración entre los diferentes grupos, las formas mediante las cuales se produjo tuvieron ciertas características que podrían considerarse muy propias, y hasta únicas del Chaco. Dichas formas, de las cuales aquí solo hemos descripto las inherentes a la vinculación social, se manifestaron fundamentalmente a través de la participación en entidades aglutinantes, como las asociaciones mutualistas o las cooperativas agrícolas; en las actividades recreativas organizadas con fines benéficos; en la asistencia a festividades patrias; y ya en el ámbito rural, en los espontáneos encuentros en espacios de concurrencia común.

Sin embargo, aun cuando hemos hecho algunas distinciones entre grupos, ámbitos, y formas, no podríamos sin embargo determinar una estratificación de esta sociedad en esta época. Es que un pasado común de privaciones y la convivencia en un espacio nuevo y libre de prejuicios, tendieron a limar las diferencias del conjunto, antes que a marcarlas.

Por estas razones se suele aludir al componente social del Chaco como un "crisol de razas"; de hecho, un crisol tan heterogéneo que hasta el día de hoy es difícil establecer una identidad típicamente chaqueña y reconocible como tal, encontrándose por doquier muestras del acervo cultural propiamente correntino, santiagueño, salteño o paraguayo, y también desde luego, del amplio abanico de nacionalidades europeas aquí representadas.

\section{Fuentes}

\section{Fuentes primarias}

\section{Archivos}

Archivo Histórico de la Provincia del Chaco (En adelante AHPCH). Gobernación del Chaco. Memoria Presentada al Superior Gobierno de la Nación por el Gobernador José Castells, correspondiente al año 1934. Resistencia, 1935.

AHPCH, Gobernación del Chaco. Memoria Presentada al Superior Gobierno de la Nación por el Gobernador José Castells, correspondiente al año 1936. Resistencia, Imp. Juan Moro, 1937. 
Formas de integración social en un espacio en construcción. El caso del Territorio Nacional...

AHPCH, Gobernación del Chaco. Memoria presentada al Ministerio del Interior por el gobernador del Territorio Nacional del Chaco, José Castells, correspondiente al año 1935. Resistencia: Ed. de la Gobernación del Chaco, 1936.

AHPCH, Gobernación del Chaco. Memoria Presentada al Superior Gobierno de la Nación por el Gobernador José Castells, correspondiente al año 1936. Resistencia: Imp. Juan Moro, 1937.

AHPCH, República Argentina. Informe del Inspector del Departamento del Trabajo, José Elías Niklison. En: Boletín del Departamento Nacional del Trabajo $n .{ }^{\circ} 32,1915$.

AHPCH. Copiadores de la secretaría de la gobernación, Gobernador Castells. $1^{\mathrm{o}} \mathrm{de}$ diciembre de 1933.

Gobierno del Territorio Nacional del Chaco: Album Gráfico Descriptivo. Bs. As. 1935.

\section{Publicaciones periódicas}

El Imparcial, de P.R, Sáenz Peña, 1925-26.

Estampa Chaqueña, Resistencia, 1930-1942.

La Voz del Chaco, Resistencia, 1930.

\section{Libros}

República Argentina. Tercer Censo Nacional 19l4., t. V. Bs. As.: Tall Gráf. Rosso, 1917.

República Argentina. Ministerio del Interior. Asesoría Letrada de Territorios Nacionales. Censo General de los Territorios Nacionales, 1920, t. I. Bs. As.: Establec. Gráf. A de Martino, 1923.

República Argentina. Ministerio de Agricultura de la Nación. Censo Nacional Agropecuario 1937. Bs. As.: Ed. Kraft Ltda., 1939.

República Argentina, Ministerio de Agricultura, Junta Nacional del Algodón. Cosecha Mecánica del Algodón. Estudio preparado por los Ingenieros Agrónomos Rafael García Mata y Rómulo Franchelli. Buenos Aires, 1942.

Reyna, Máximo (recop.). Código Rural para los Territorios Nacionales, 1902-1910. Ministerio del Interior: Bs.As, 1910.

\section{Fuentes Secundarias}

\section{Libros}

Beck, Hugo. Inmigrantes Europeos en el Chaco. Transición del pluralismo al crisol. Cuadernos de Geohistoria Regional, n. ${ }^{\circ}$ 39, IIGHI. Resistencia: Chaco, 2001. 
Lestani, Juan Ramón. El Territorio Nacional del Chaco. Geográfico, Económico, Social. (Oro y Miseria). Resistencia: S/Ed, 1935.

Lestani, Juan Ramón. Por los Caminos del Chaco. Resistencia: Ed. Librería de la Paz, 2010 (reedición).

Miranda, Guido. Tres Ciclos Chaqueños. Crónica Histórica Regional, ResistenciaChaco. Argentina: Edit. Norte Argentino, 1955.

Pavlotzky, José. Esta Tierra es Mía. Buenos Aires: El Ateneo, 1947.

Suáiter Martínez, Francisco. Los Territorios. Buenos Aires: Instituto Cultural Joaquín V. González, 1943.

\section{Capítulos de libros}

Borrini, Héctor. “La Colonización como Fundamento de la Organización Territorial del Chaco (1930-1953)", en Cuadernos de Geohistoria Regional, n. ${ }^{\circ} 19$. Resistencia: IIGHI-CONICET, 1987.

Leoni, María Silvia. "Territorios Nacionales", en Academia Nacional de la Historia, Nueva Historia de la Nación Argentina. Buenos Aires: Planeta, 2001, t. VIII.

Mari, Oscar Ernesto. "Inseguridad y Bandidaje en el Territorio Nacional del Chaco 1918-1940”, en Cuadernos de Geohistoria Regional, n. ${ }^{\circ}$ 30. Resistencia: Instituto de Investigaciones Geohistóricas, CONICET, 1994.

Schaller, Enrique. "La Colonización en el Territorio Nacional del Chaco en el período 1869-1921", en Cuadernos de Geohistoria regional, n. ${ }^{\circ} 12$. Corrientes: IIGHICONICET, 1986.

\section{Artículos en revistas}

Bruniard, Enrique. El Gran Chaco Argentino (Ensayo de Interpretación Geográfica), en Geográfica, n. ${ }^{\circ}$ 4, Resistencia, UNNE, 1975-78.

Mari, Oscar Ernesto. "La transición entre dos ciclos y sus efectos sociales en un territorio argentino. Conflictos de convivencia en Chaco ante una nueva etapa colonizadora (1920-1940)", en Revista de Geografía Norte Grande, n. ${ }^{\circ}$ 42, Universidad Católica de Chile, 2009.

\section{Publicaciones en internet}

Bandieri, Susana. "Cuando crear una identidad nacional en los territorios patagónicos fue prioritario", en Revista Pilquen, Neuquén, Facultad de Humanidades, Universidad Nacional del Comahue. Sección Ciencias Sociales, año XI, n. ${ }^{\circ}$ 11. http://www. Revista-pilquen.com.ar/Ciencias Sociales (agosto 3 de 2009). 